\title{
Social Network Analysis (SNA) on \#Kristengray Hashtag: Understanding Gentrification Side Effects Behind the Digital Nomad Phenomenon
}

\author{
Mohammad Thoriq Bahri' ${ }^{1 ;}$ Derajad Sulistyo Widhyharto ${ }^{2}$ \\ Directorate General of Immigration, Ministry of Law and Human Rights Republic of Indonesia ${ }^{1}$ \\ Department of Sociology, Faculty of Social and Political Science, Universitas Gadjah Mada ${ }^{2}$ \\ muhammad.thoriq.bahri@gmail.com |derajad@ugm.ac.id
}

\section{ABSTRACT}

Indonesia is one of the destination countries for the digital nomads in South East Asia. Digital Nomad can be described by the person who combines work and leisure activities, without geographical borders. The digital nomad lifestyle is becoming a trend after an American tourist, Kristen Gray, went viral on the Twitter Platform. She promoted Bali as a heaven for the digital nomad because of the low cost of living and cultural openness by selling eBook and open consultation services for the people who live in the American and European continents, then she deported by the Indonesian Immigration Authorities, charged with the misuse of visas (she was used tourism visa for business purposes). Then, the research question arises, are there potential gentrification effects of digital nomad lifestyle to the local people? And what should the government do to tackle this issue? This research is conducted by analysing tweets using the \#kristengray and \#digitalnomad hashtag, obtained from January 12 to March 21, 2021. The results are more than 49 percent of users, which dominated by the foreigner is defending Kristen Gray, and forcing the Indonesian government to open Bali as digital nomad living places, but 51 percent of users, who dominated by Indonesian is refusing what the Kristen Gray doing, by arguing if Bali is purely just for tourism places. The results show that gentrification is potentially happening between the digital nomad and residents, because of the difference in economic level, culture and value. Then, the government should consider making a policy to minimize the effects of gentrification resulting in digital nomad activities, suggesting open special visas with the restriction and tax policy for the digital nomad.

Keywords: Millennial Workers | Immigration | Gentrification | Digital Nomad | Bali

\section{BACKGROUND}

Indonesia is the second of the most visited countries in Southeast Asia (LSPR, 2019). In 2019, the number of foreign tourists visiting Indonesia reached 16.11 million visits, an increase of 1.88 percent compared to the number of foreign tourists visit in the same period in 2018, which totalled 15.81 million visits (BPS, 2020). The data show that the largest number of foreign tourists came from the Asia Pacific with a total of 13,019,345 tourists, European tourists as many as 2,075,864 people, and from the American continent as many as 648,903 tourists (BPS, 
2020). Most of them visit Bali, Lombok, and Yogyakarta as the most popular destinations for tourism activities.

The contribution of the tourism sector to the National GDP in 2014 was 9.3\% of the total GDP or Rp 946.1 trillion. This figure shows an increasing trend compared to the previous year amounting to $9.2 \%$ of the total GDP or amounting to 886.7 trillion. In 2015, it was estimated that the tourism sector would contribute 1,012.7 trillion to total GDP or grow by $7 \%$. The labour absorbed from the tourism sector also experienced a significant increase. According to the WTTC, the total contribution of the tourism sector to employment in 2014 was 9.8 million workers ( $8.4 \%$ of the total workforce). It is estimated that this contribution would increase by $3.3 \%$ in 2015 or 10.1 million workers can be absorbed in the tourism sector. This contribution still has great potential to increase by considering factors of competitiveness of tourist destinations 'destination competitiveness' such as natural tourism resources, culture, history, and prices (Kemenkeu, 2016).

There are not only positive economic impacts from the tourism sector but also negative impacts. The negative impacts of the increasing number of foreign tourists are the number of immigrationrelated cases. The General Directorate of Immigration released 5150 immigrationrelated cases that happened during the 2020 period. The 58 cases were pro Justitia cases, a rapid increase from the previous year which recorded 2,187 cases (Dirjen Imigrasi, 2021).

Kristen Gray, an American tourist who visited Bali during the period of 2020 is one of the best examples, which is becoming viral in the early year of 2021 is one of the immigration-related cases. Kristen Gray and Her Girlfriend landed in Bali on January 17, 2020, and on December 22, 2020, she extended her residence permit at the TPI Denpasar Class I Immigration Office and is valid until January 24, 2021. The visa exemption done by Kristen Gray is relevant to the regulation of the Ministry of Law and Human Rights Number M.HH01.GR.03.01/2020 (Kemenkumham, 2021). The effect of that regulation is that many of the tourists who already landed in Indonesia cannot go back to their countries.

The closing border policy creates a new phenomenon that existed in the era of the COVID-19 pandemic called Digital Nomad. Digital Nomad is a person who works from a location of his choosing by utilizing wireless digital technology (Kompas, 2020). Digital Nomads can work without location barriers and can even be done while visiting certain places they like. Therefore, most of the Digital Nomads tend to move from place to place (nomads). Many tourists during the COVID-19 pandemic are staying and working in Indonesia as Digital Nomad, one of the reasons is because they cannot go anywhere because of the mobility restriction policy.

Kristen Gray is one of the digital nomad workers, based on the news releases by the Ministry of the law and human rights, Kristen Gray has 2 (two) main mistakes. Firstly, during her stays in Indonesia, Kristen Gray proposed many of the nomad workers live in Bali, because of the low cost of living and no income tax by conducting consultation services to avoid punishment by health protocol rules to outsmart visa overstay in Indonesia. The invitation to move to Bali during the pandemic contradicts the Circular of the Head of the Covid-19 Handling Task Force Number 2 of 2021 concerning International Travel Health Protocols in the Covid-19 Pandemic Period. As well as a Circular Letter of the General Director of Immigration Number: IMI0103.GR.01.01/2021 concerning Temporary Restrictions on Foreigners Entering Indonesian Territory During the Covid-19 Pandemic. Secondly, she promoted if Bali supports the lesbian, gay, bisexuals, dan transgender community by using her social media accounts (Kumparan, 2021). 
From the law perspective, she's doing business in Indonesia by selling her services US\$ 450 per hour with the tourism visas and violates local customs by promoting the lesbian, gay, bisexuals, dan transgender community. She was charged with two law consequences. Firstly, article number 75 (1) law number 6/2011 about immigration because of the abuse of visas. Secondly, article number 122 (a) law number 6/2011 about immigration because of promoting the lesbian, gay, bisexuals, dan transgender community (Hukum Online, 2021). She was deported back to the United States on January 21, 2021.

The digital nomad phenomenon is a new way of work, and increases slightly during the pandemic happening in the world right now. Pattaya in Thailand and Bali in Indonesia are chosen by most of the European digital nomads because of their openness and hospitality (Haking, 2017). On the other hand, most of the digital nomad workers are 19 to 36 years old, which can be concluded that most of them are millennial workers seeking freedom (Cook, 2020). Then, as the destination countries for the digital nomad, this research is willing to understand the phenomenon that may happen behind that phenomenon, by using those research questions: 1) How the social communication pattern of digital nomad phenomenon in the \#Kristengray hashtags? 2) How is the digital nomad phenomenon in Bali creating gentrification? 3) What has the government proposed to do related to this phenomenon?

This research will be conducted by using Twitter big data with the \#Kristengray and \#digitalnomad hashtag obtained from January 15 to March 12, 2021. The Social Network Analysis will be used with the RStudio tools for the sentiment analysis and Gephi Software for the conversation network mapping. The results will be analyzed with the theory of gentrification.

\section{LITERATURE STUDY}

The Digital Nomad Lifestyle

The Digital Nomad is one of the new phenomena happening recently around the world, the word "digital nomad" first known used in 2015 in a community of freelance workers in the United States which use some online working platforms like freelancer.com, fiverr.com, and gigs.com, and the fact is the academic literature which discusses this phenomenon is still very limited till today (Olga, 2020). The millennials who are beginning to work, start to break the regular working style, which requires 8 hours of working every day, 5 days a week. Based on the data, in Europe and America only, more than $42 \%$ of millennial workers are going on vacations regularly to reduce their stress, while $34 \%$ of millennial workers are trying to find something new to explore (Sofronov, 2018). The millennial workers' holiday expectation is relatively high, but most of them are restricted by their employment contracts, then the digital nomad movement is one of their alternative ways to work without depending on the employment contract (European Commission, 2016).

Recently, the number of people working as digital nomads has increased rapidly. The digital nomad lifestyle can be described as a movement that eliminates the traditional way, which separates work and travel, furthermore, the digital nomad movement gives the alternative way by combining work and travel activities at the same time. One of the academic discussions is explaining the digital nomad as "that leverage digital technologies to perform their work duties, and more generally conduct their lifestyle in a nomadic manner" (Mohn, 2014). The digital Nomad is one of the side effects of the digital public sphere, which happens because of the creation of the "digital work". The digital work itself is defined as the work 
which focuses on the output-based work (Nash et al, 2017).

The development of the internet is enabling people to work anywhere, which mostly did by people who are 20 to 40 years old and motivated by the motivation to travel, digital work, deadline-based work, and nomadic lifestyle with the main reason are gaining professional autonomy and maintaining self-assured stability (Prester et al, 2019).

On the other hand, the digital nomad lifestyle is offering flexibility in mobility and working procedure, which increase attention in between the millennials. However, the traditional way of work which focuses on productivity, employment relationship and deadlines are still becoming the way of work in the digital nomadism lifestyle (Thompson, 2019). But, the most important characteristic of the digital nomad is the existence of international travel with the semipermanent residence and ongoing basis.

Furthermore, the digital nomad lifestyle also depends on the immigration policy which differs in every country, their lifestyle preferences are depending on the visa policy and traditional working relation factors, but with flexibility, international mobility has been defined as a core element of such travels (Reichenberger 2018; Thompson 2018, 2019). Those key factors are separating the digital nomad phenomenon compared with travel or leisure activities. The conclusion of the digital nomad lifestyle can be described as follows:

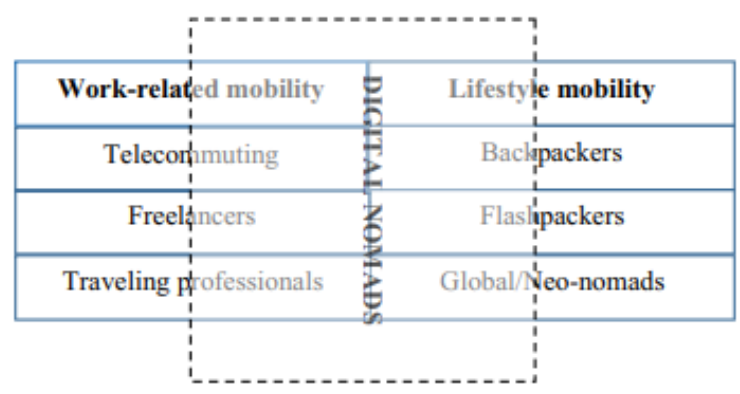

Figure 1. Digital Nomad Lifestyle. Source: Olga, 2020
Based on the several academic literature above, the digital nomad can be described as one of the varieties of leisure activities with the professional working culture. The development of the internet, digital working platforms such as freelancer.com, fiverr.com, and gigs.com is enabling the new working culture which is popular in the millennial worker's segment. However, the digital nomad lifestyle is eliminating the patron-client relation in the traditional working culture. The digital nomad is bringing a new way of flexibility that never existed before. They do not depend on the spatial location and certain working hours - the digital nomads eliminate the restriction of space and international borders. Then, how can the Social Network pattern trigger the digital nomad lifestyle? That question will be argued in this paper by analyzing related hashtags in the Twitter social media platform.

\section{Gentrification in digital lifestyle}

The gentrification term first appeared in 1964 with the originator Ruth Glass who was an urban expert. There is no certain definition of what gentrification is so that many opinions and opinions of experts have tried to translate the meaning of this phenomenon. According to Lees et.al (2007), gentrification is a process of transforming social class or a piece of vacant land in an urban area that was previously inhabited by lower-class people into a middle-class area which is usually designated as a commercial area. So that gentrification is often associated with a form of adjustment to the needs of the middle class or capitalists. Gentrification tends to occur in areas that are located close to middle-upper class residential areas (Guerrieri, 2013), close to the city center (Helms 2003), areas traversed by mass transportation services (Helms, 2003), and in areas that have stock. old housing (Kolko, 2007). Gentrification also has the potential to cause the displacement of the lower-class when upper-middle economic 
groups come and settle in an area which increases rental prices, raw material prices, and service prices so that it will indirectly make the lower-class unable to survive and move from the area (Atkinson, 2000). However, gentrification is also touted as a tool that can bring positive urban economic development in the right direction, although sometimes the negative impact is more pronounced.

The phenomenon of traditional gentrification refers to gentrification or changes in urban demographic and sociospatial conditions, which causes public upheaval against the process. (Pratiyudha, 2019). The rapid transformation of the traditional values, from the old culture to the new culture creates gentrification.

The effects of traditional gentrification can be explained by research conducted by Saratri Wilonoyudho (2019) that explains that the City of Semarang, Indonesia, concluded that urban transformation created a rapid increase in the number of the informal sector and other unskilled workers. In the area around Semarang, there has been an urbanization trend with a pattern of distribution characterized by high urban population growth. The central determinant of inmigration to Semarang City is the simultaneous combination between rural pressures and urban attractiveness that are seen to always provide employment. The impact of migration on the city of Semarang is urban involution and environmental degradation.

As with colonialism, gentrification not only robs local people of power and weakens their economic conditions, but also involves an imbalance of social and racial conditions. Gentrification encourages capitalism through market demand (real estate development) but at the same time gets people who live in the area first. The movement of the lower-class society can then be divided into two types based on their characteristics. Firstly, displacement due to coercion (involuntary). And the second is the process of moving carried out independently or often referred to as voluntary. Although many studies say that gentrification will harm marginalized communities and deprive them of their rights to life, there are also many research results and expert opinions that say that gentrification also has a positive impact on people's lives, especially on the future development of urban areas. According to Atkinson (2002), gentrification is a process that supports efforts to revitalize and improve urban areas. Gentrification is considered by some as a good sign for economic growth.

On the other hand, gentrification is also argued to be happening in the digital lifestyle. The internet is having a big role in increasing the inequality between the users via the social media platform, which can trigger a gentrification phenomenon (Smith et al, 2016). The digital lifestyle can trigger gentrification because it creates several conditions relevant to the traditional gentrification phenomenon. Firstly, the Isolation phenomenon which is increasingly happening, people tend to refer to the internet for their daily life (Gil-Or, 2011). This condition is isolated by living in the same neighborhood with relatively different income levels and even having different social or cultural values compared with their neighborhood (Yavich et al, 2019). Secondly, the internet is Increasing social costs. The internet keeps spreading up the values of a neighborhood and indirectly increases the living cost, resulting in raising property values and taxes. The increasing costs make the previous communities unable to afford the social cost which increased by the internet. The effects are the separation between "the have " and "the haven't" then the gentrification phenomenon will be happening (Lingel, 2019). Thirdly, the uneven commercialization refers to the destruction of local businesses that previously supported the existing society, replaced by the "virtualization" of new business concepts (Kusumadjaja, 2014). 
The gentrification phenomenon is very broad and must be anticipated by the local parties to minimize the negative social impact. The Digital Nomad is potentially creating gentrification, then how the gentrification will be happening by the digital nomad in Bali Island as the most visited destinations will be argued through this paper.

Kristen Gray and Digital Nomad Phenomenon in the Aspects of Immigration

On January 17, 2021, the figure of Kristen Gray was a hot topic of conversation among Twitter netizens. Initially, Kristen Gray wrote viral Tweets because she also invited other foreigners to stay in Bali during the Covid-19 pandemic, in which the Javanese and Balinese people implemented Large-Scale Social Restrictions (PSBB). The General Directorate of Immigration responded quickly to these Tweets by investigating the whereabouts of the person concerned. Two days later, the Regional Office of the Ministry of Law and Human Rights in Bali issued a Press Release Number: W20.HM.01.02-595 confirmed that Kristen Gray was suspected of violating Article 75 paragraph 1 and Article 122 letter of Law Number 6 the Year 2011 concerning Immigration.

These two articles are imposed based on the @kristentootie Twitter account whose invites foreigners to move to Bali during the pandemic as opposed to the Circular of the Head of the COVID-19 Handling Task Force Number 2 of 2021 concerning International Travel Health Protocols in the Covid-19 Pandemic and the Director's Circular General Immigration Number: IMI-0103.GR.01.01 the Year 2021 concerning the Temporary Restriction of the Entry of Foreigners into Indonesian Territories during the COVID-19 Pandemic Period. In addition, Kristen Gray is suspected of carrying out business activities through selling e-books and installing Bali tourism consulting rates while she only holds a visit visa as a basis for entering and staying in Indonesia.

What's interesting is that after the press conference, Coconuts Bali (a local English-language online news website) wrapped up the news and classified Kristen Gray as an American digital nomad (a digital nomad from the United States) (Coconuts Bali, 2021). However, in essence, the immigration rules regarding digital nomads are still concerned as a grey area.

The regulations on digital nomads have not been comprehensively regulated and are subject to positive immigration penalties. Provisions regarding foreigners working in Indonesia (TKA) are regulated in the Regulation of the Minister of Law and Human Rights Number 24 of 2016 as amended by Regulation of the Minister of Law and Human Rights Number 51 of 2016 concerning Technical Procedures for Application and Granting of Visit Visas and Visas Limited Stay, Regulation of the Minister of Law and Human Rights Number 16 of 2018 concerning Procedures for Granting Visas and Stay Permits for Foreign Workers and Regulation of the Minister of Law and Human Rights Number 26 of 2020 concerning Visas and Stay Permits during the Adaptation of New Habits. These rules do not specifically regulate digital nomads because foreign workers are included in the work guaranteed by companies in Indonesia. Therefore, when applying for a Limited Stay Visa for work.

Actually, in article 25 the regulation of the Minister of Law and Human Rights Number 24 of 2016 regulates limited stay visas in the framework of work which can be given to foreigners who are on vacation but the regulated work is limited to the fields of education, tourism, health, social, sports, and cultural arts, no which explains about digital nomads.

\section{METHOD}


This research was conducted by using the descriptive qualitative with the Social Network Analysis (SNA) approaches. A social network is a set of actors (points or nodes) that may have a relationship (edge or bond) with one another. The basic perspective in social networks is that through social ties, individuals gain access to information, social support, and other resources (Agneessens et al., 2017). Networks in a social network can have few or many actors, and one or more types of relationships between pairs of actors. The starting point is needed in the analysis of social network patterns to find out all the relationships between each pair of actors in the network. The resulting pattern will be visualized in a form graph.

The components that model social networks (Manik et al, 2017), namely: (1) Node or node. A group of people, objects, or events that are represented by dots, or in other words, are called actors; (2) Tie or tie. The connection between one point and another in the network is represented by a line, (3) Flow, in the diagram is represented by an arrow, which describes something that flows from one point to other points through bonds that connect each point in the network. The components of a social network can be related to each other if the bonds that connect one actor to another are relatively permanent (there is an element of time/duration). This series of bonds causes a group of actors to be categorized as a unit that is different from one another. The channels or paths that must be traversed by actors do not occur randomly, but there are certain patterns. The pattern that is formed is based on the rules governing the relationship of each actor, the relationship between one actor and another, and the relationship between all actors and central actors.

SNA can visualize structural or hierarchical characteristics in a social network. One of them is an institutional social network that can assist in organizational analysis. The analysis is represented in the form of a particular sociogram (network image), such as integration and regulation. SNA theory is used to analyze the relationship between nodes or actors in a social network by utilizing graph theory (Tomasoa et al, 2019). The SNA approach is developed to identify the most important actor in a graph with the concept of centering or centrality.

In this research, the data that will be analyzed is the hashtags \#kristengray and \#digitalnomad from the Twitter platform, obtained from January 21 to March 12, 2021. The data SNA analysis performed by using the Gephi opensource software Version 0.92 for the conversation network analysis, and $\mathrm{R}$ Studio Version 1.3.1093 software for the sentiment analysis. The results will be analyzed with the theory of gentrification to understand the pattern of the digital nomad phenomenon, especially which is happening in Bali Island, Indonesia.

\section{Finding and Analysis}

After conducting theSocial Network Analysis, the conversation pattern of the conversation network using the \#kristengray and \#digitalnomad hashtag can be described as follows: 


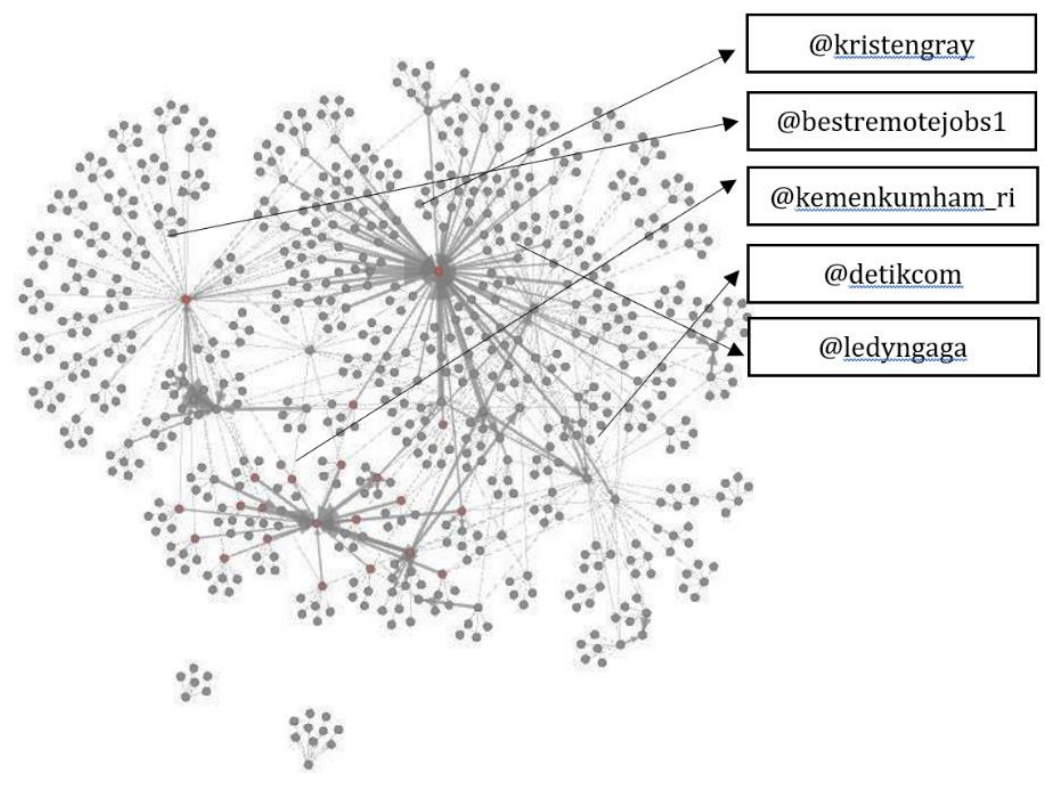

Figure 2. Conversation Mapping in the Hashtag \#kristengray and \#digitalnomad. Source : Data Analysis

Then, it can be desribed if the most active user which act as the influencer can be desribed as follows :

\begin{tabular}{|l|l|}
\hline \multicolumn{1}{|c|}{ Most Active Users } & Most Influential Users \\
\hline Detikcom & Kemenkumham_ri \\
\hline ledyngaga & ledyngaga \\
\hline danlawrence & bestremotejobs1 \\
\hline pm_results & W_clicks \\
\hline marvinliao & sarora27 \\
\hline renzlopezfeph & funnelexpertph \\
\hline mer_anoto & standardluggage \\
\hline career_vault & nomadgirls \\
\hline devvibesbot & workpuls \\
\hline moqil & planetearthtrav \\
\hline benasque_ & mikeschiemer \\
\hline nomadgirls & asiaonecom \\
\hline
\end{tabular}

Table 1. Most Active and Most Influential Users in the hashtag \#kristengray and \#digitalnomad. Source : Data Analysis

After understand the most active users and most influential users, the sentiment analysis is conducted by using the RStudio Software with the lexicon dictionary. Also, for the Indonesian language, the authors are doing the manual data cleaning. The sentiment analysis can be described as follows: 


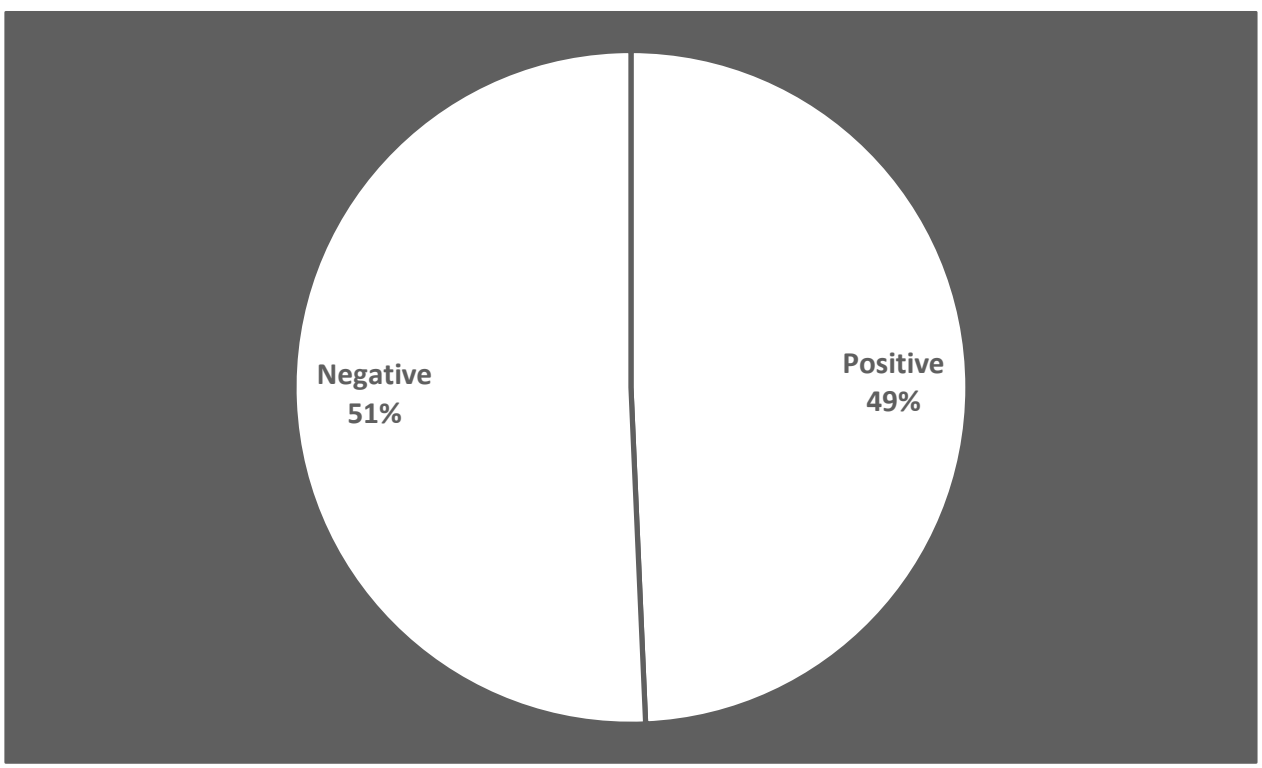

Figure 3. The results of Sentiment Analysis in the hashtag \#kristengray and \#digitalnomad. Source: Data Analysis

After analyzing the sentiment that happened on Twitter, the result shows that 51 percent of users who implement \#kristengray and \#digitalnomad stated negatively about what Kristen Gray did in Bali. Most of them are proposing to the General Directorate of Immigration to deport Kristen Gray and her girlfriend as soon as possible. On the other hand, 49 percent of the \#kristengray and \#digitalnomad users stated that they support what Kristen Gray doing in Bali as the Digital Nomad. Then, the most read and retweeted tweets shown as follows:

\begin{tabular}{|l|c|}
\hline \multicolumn{1}{|c|}{ Conversation records } & Value \\
\hline $\begin{array}{l}\text { Gw antara kasihan/sedih/miris \& pgn ketawa } \\
\text { liat org kita yg getol belain Meghan Markle }\end{array}$ & NEGATIVE \\
\hline $\begin{array}{l}\text { You don't know how much I really adore krist } \\
\text { and singto }\end{array}$ & NEGATIVE \\
\hline $\begin{array}{l}\text { Have you seen this new trend? These are two } \\
\text { U.S. citizens living in Bali openly plotting to } \\
\text { pay Indonesian doctors to forge COVID } \\
\text { vaccine certificates. }\end{array}$ & POSITIVE \\
\hline $\begin{array}{l}\text { Drop your comments and see what you really } \\
\text { think about it. } \\
\text { "Indonesians Would Like to Thank You, } \\
\text { Kristen Grey!" }\end{array}$ & POSITIVE \\
\hline $\begin{array}{l}\text { Well, this whole thing went left } \\
\text { quick......supporting her to open Bali as Digital } \\
\text { Nomad Paradise }\end{array}$ & POSITIVE \\
\hline
\end{tabular}




\begin{tabular}{|l|l|}
\hline $\begin{array}{l}\text { To those still thinking that Kristen Gray's case } \\
\text { was about her race. } \\
\text { Nope, Indonesia just deported another white } \\
\text { tourist!! }\end{array}$ & NEGATIVE \\
\hline $\begin{array}{l}\text { However, the reason why the details are } \\
\text { unclear is partly because the Indonesian } \\
\text { system is so unclear. Bali is meant to be } \\
\text { closed to foreigners, but the regulation is } \\
\text { unclear. }\end{array}$ & POSITIVE \\
\hline
\end{tabular}

Table 2. The most read and retweeted conversation between the Twitter users who implement \#kristengray and \#digitalnomad hashtag. Source: Data Analysis

Based on the results explained above, we can conclude that the user who has a role as a conversation starter is @ kristengray, then after her Tweets about becoming a digital nomad In Bali becoming viral, most of the users who act as Active engagers (the users who spread the information in their network), can be identified as @ bestremotejobs1, @kemenkumham_ri, @ detikcom, and @ledyngaga, those users influence their followers to spread the information, whether the information is positive or negative. Then, after the information is spread across the conversation network, several users give feedback, together with their followers is called Network Builder.

The interesting findings are that many users who came from overseas, mostly from the European and American continent are trying to defend what Kristen Gray is doing. For Example, one of the tweets posted by Ryan Albrey, an American, said "However, the reason why the details are unclear is partly that the Indonesian system is so unclear. Bali is meant to be closed to foreigners, but there are no clear rules here". Based on the data analysis, other users who actively giving positive feedback and defend what Kristen Gray did as Digital Nomad are @danlawrence, @ @m_results, @marvinliao, @ @ @mer_anoto, @ career_vault, @devvibesbot, @moqil, @benasque_, $@$ nomadgirls. Most of those accounts have come from the United States.
On the other hand, many users who came from Indonesia, have negative feedback about Kristen Gray. Most of them are supporting the Immigration Authorities to deporting Kristen Gray back to the United States, the most active users who refusing Kristen Gray as a digital nomad in Bali island can be analyzed as @RaniIndraswari, @adityalolong20, @wase, @AMCC, @A'ashimatul hilmiyah, @hanyamanusia, and @K-Fear. Those results will be analyzed with the theory of Gentrification in the next chapter.

\section{DISCUSSION}

\section{Explaining of the Research Findings}

According to the data above, we can conclude that many of the digital nomads from the American and European countries are proposing to open Bali as the Digital Nomad hosting place, with the total positive arguments reaching up to 49 percent. This argument is supported by the digital platform for the digital nomad (https://nomadlist.com), which stated Bali is the most favorite place for the digital nomad. Based on the Nomad List users, Bali is chosen because of the low cost of living (around US\$ 1337/month), and openness to the tourist by 235 users. On the other hand, many locals are trying to argue if Bali is not a suitable place for the digital nomad by attacking Kristen Gray's social media. The negative arguments about the \#kristengray and \#digitalnomad reach up to 
51 percent, dominated by the Indonesian users. Most of them said if the digital nomad will harm the local people, because of the different culture, standard of living, and even potential violation of the immigration law.

Analysing what really happening in Bali before the Kristen Gray cases

The social effects of the Digital Nomad phenomenon are still questionable. However, the research findings said that people who are identified came from rich countries, trying to look for countries with a lower cost of living and cultural openness like what Kristen Gray did. As stated in the literature review, because the technology development is changed how the labor market works, which expected that people who came from the advanced economies will get an advantage in adopting the digital nomad lifestyle, this argument is relevant to the origination of the digital nomad, which can be shown as follows

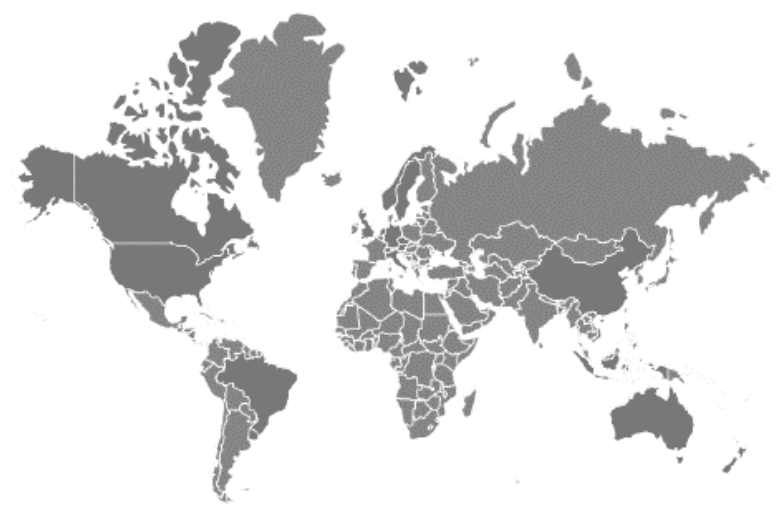

Figure. 4. The Digital Nomad Originating Countries (Dominated by the Advanced Nation Economies). Source: Haking 2017

Based on the research conducted by Reichenberg (2017) the motivation to become a digital nomad in Bali is mostly because of the satisfying social comfort, low living cost, and high technical skills supported by the great internet coverage. The top three Originating countries of the digital nomad in Bali are the United States,
Germany and the Netherlands. Consistent with Reichenberg's (2017) definition of a digital nomad, the results show that the majority are young professionals/millennials: 72 percent are 25-34, 19 percent are $35-44,7$ percent are 18-24 and 2 percent are $45-54$

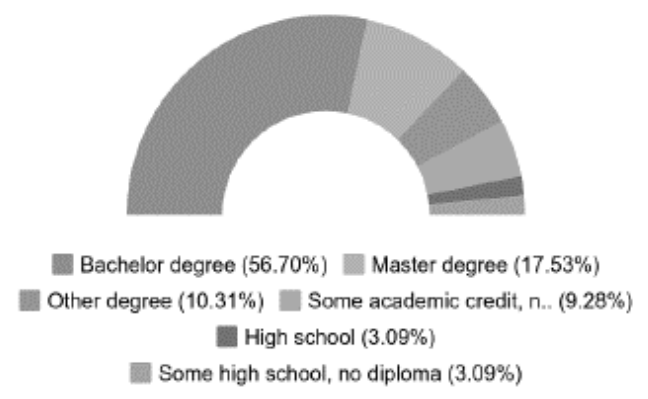

Figure 5. The level of education of the Digital Nomad.

Source: Haking, 2017 
Formica (2013) suggests that millennials are the true protagonists of innovation and are explorers and self-evident digital nomads. As computers enter territory previously ruled by humans, Figure 5 shows that most digital nomads have academic degrees. Knowledge is the

\section{Potential Gentrification effects of Digital Nomad}

The potential of the gentrification Phenomenon may happen in Bali as a primary destination for the Digital Nomad. The technological and economic gap between the American and European Millennials who work as Digital Nomad and local people in Bali is relatively high.

Based on the research conducted by Prabawa and Pertiwi (2020) in Canggu, Bali found that 80 percent of Digital Nomad who lived in Bali are aged between 20 to 30 years old. Another interesting fact is most of them are very well educated, with only around 9\% only finished secondary school education, then more than 33 percent hold a Master or Ph.D. degree and the rest already hold a bachelor degree. Surprisingly, about 27 percent of the digital nomads who lived in Bali have a relatively individual's comparative advantage, while an academic degree can facilitate the execution of entrepreneurial ideas and benefit negotiations in contractual agreements for more favorable conditions, among others.

high income, around $\$ 3,000$ to $\$ 5,000$, followed by 35 percent earning around $\$ 1,000$ to $\$ 3,000$ per month. Relevant to Kristen Gray "promotional materials" in her tweets, the research conducted by Takama (2020), found if most of the digital nomads are choosing Bali as their working base because of the low cost of living, cultural openness, and surprisingly, because they don't need to pay income taxes. Then, it can be concluded why most of the digital nomad communities are defending Kristen Gray because, in Bali, they can enjoy a high standard of living without paying income taxes.

On the other hand, when we compare those facts with the Bali local economy, the local workers' income is still very low if compared with the digital nomad monthly income, the average income for the local worker in Bali is US\$ 170,30 per month, the detailed data as explained below:

\begin{tabular}{|l|c|l|}
\hline \multicolumn{1}{|c|}{ District } & 2020 & $\begin{array}{c}\text { In US\$ (Per 13 April 2021 }= \\
\text { US\$1 Equal to IDR 14.641 }\end{array}$ \\
\hline Jembrana & 2.557 .102 & 174,65 \\
\hline Tabanan & 2.625 .217 & 179,31 \\
\hline Badung & 2.930 .093 & 200,13 \\
\hline Gianyar & 2.627 .000 & 179,43 \\
\hline Klungkung & 2.538 .000 & 173,35 \\
\hline Bangli & 2.494 .810 & 170,40 \\
\hline Karangasem & 2.555 .469 & 174,54 \\
\hline Buleleng & 2.538 .000 & 173,35 \\
\hline Denpasar & 2.770 .300 & 189,22 \\
\hline Bali Province Average & 2.493 .523 & 170,30 \\
\hline
\end{tabular}

Table.3. Bali Provinces local workers average income in US\$.

Source: BPS Provinsi Bali, 2020 
Most of the Bali local workers are dominated by the Millennials generation, the number reaches up to 74,32 percent with the range of age from 15 to 35 years old (BPS Provinsi Bali, 2020). In terms of education, most of Bali's local workers have a high school degree ( 35,5 percent), elementary school degree (20,8 percent), middle school degree (17,77 percent), and never going to school (14,92 percent). Surprisingly, only 9,93 percent of local workers have Bachelor's or Master's degrees (BPS, Provinsi Bali, 2020). On the other hand, computational knowledge is very important for the millennials generation to catch up with the digital nomad, based on the research conducted by the Indonesian Presidential Studies (2020) in the 34 provinces with 1200 respondents, 57 percent of the respondent is agreed if the knowledge in Information Technology is very important to get a job in the modern era. But, the computational literacy in Indonesia, especially in Bali is still relatively low.

From the comparison above, gentrification will happen because of several main reasons. First, the existence of digital nomads is increasingly clarifying the welfare gap between the Indonesian people and tourists in general. With the difference in income and relatively low cost of living, digital nomads can live in luxury in the country destination. Later gentrification phenomenon unavoidable, namely phenomena immigrant society or digital nomads in accessing better accommodation from the local community. It is then resulting in the marginalization of society locally in their hometown alone.

Second, our human resources are still lagging behind other countries. Although Indonesia is entered as the fifth country and the world's largest internet user, however, the majority of people use the internet in Indonesia for leisure or entertainment, not in the context of activities production. Disparities in human resources This era of hyper-connectivity is increasingly felt in a rural area that is just dwelling on conventional economics, like trading or rent out accommodation in the area of travel.

Third, the Indonesian people are still do conservative towards outside values. With the number of digital nomad inflows to Indonesia, then indirectly Indonesian people will be exposed a lot against outside values. In Gray's case, Indonesia's public attention is focused on a "queer-friendly" statement, that is, a statement Gray mentioned that Indonesia, especially Balinese people, is open to the LGBTQ minority group. The public suddenly reacts to Gray's statement, so that public opinion is formed and immigration has to deport Gray. Here then the question arises, what is the society we are ready to be exposed to values outside the value conservatives?

\section{What should the Government Do?}

The Indonesian Government should take necessary action to minimize the social effects of the digital nomadism who entering Indonesia using tourism visas. We can conclude that three main concerns must be understood by the Government. First, this kind of practice is making Indonesia lose the tax potential, especially from the foreigner who earns thousands of dollars in Indonesia territories. Secondly, from the sociology perspective, this kind of practice will be creating gentrification between the local and the nomadism, because of the economic gap and cultural difference between the digital nomadism and locals. Third, there are potential security issues that can be happened, because the nomadism will be treated as a tourist, but because of the gentrification phenomenon, they can be an object for the organized crimes practices.

Kristen Gray is doing a thousand of dollars business in Indonesia. Generally, she selling the book through her Twitter accounts, @kristentootie about how to become the digital nomadism in Bali and propose the digital nomad to entering Indonesia using the Visa Free Facilities 
during the COVID-19 pandemic. From the immigration perspective, she violating the Ministry of Law and Human Rights rules, number 24/2016 about the Technical Procedures for Application and Granting of Visit Visa and Limited Stay Visa, by misuse the tourism visa for business purposes, and the Circular of the Head of the COVID-19 Handling Task Force Number 2 of 2021 concerning International Travel Health Protocols in the Covid-19 Pandemic and the Director's Circular General Immigration Number: IMI0103.GR.01.01 the Year 2021 concerning the Temporary Restriction of the Entry of Foreigners into Indonesian Territories during the COVID-19 Pandemic Period, by proposing the foreigner to enter Indonesia during the COVID-19 Pandemic.

On the other hand, the Indonesian Government didn't have any rules or legal basis to regulate the digital nomadism who entering Indonesia as a tourist. In the Kristen Gray cases, she was suspected of violating Article 75 paragraph 1 and Article 122 letter of Law Number 6 the Year 2011 concerning Immigration. That legal basis is general rules for the immigration violation, with the only deportation as the option as a sanction, which means there no sanction for the digital nomadism who misuse their visa. Those kinds of conditions create a contra argument, local media called Kristen Gray as a legal digital nomad and said if the Indonesian Government is not ready to accept that kind of phenomenon (Coconuts Bali, 2021).

For digital nomads as described in the literature review, convenience is a fundamental element in helping to get their job done. Many of the digital nomads choose to travel while working in tourism countries, one of which is Bali. The unique fact is that Canggu (a village in Bali) is one of the most popular places for digital nomads (Scandasia, 2021).

Most digital nomads use tourist visas or visa-free visits to enter a country. They travel but on the sidelines of the tour, they do remote work. According to immigration's point of view, this is a form of violation of the use of a residence permit that can be punished by immigration administrative action or a criminal act. Working while traveling is a complicated polemic, especially digital work which is very difficult to detect because Immigration officers will not know when foreigners (digital nomads) who are sunbathing on Sanur Beach turn on their laptops to finish their work.

In conclusion, the law which regulated the digital nomad has not existed yet and is still classified as a grey area. So far, if the foreigner doing business in Indonesia, whether as workers or Investor, are regulated with the regulation of the Ministry of Law and Human Rights Number 24 of 2016 as amended by the regulation of the Ministry of the Law and Human Rights Number 51 of 2016 concerning Technical Procedures for Application and Granting of Visit Visas and Limited Stay Visas, regulation of the Ministry of Law and Human Rights Number 16 of 2018 concerning Procedures for Granting Visas and Residence Permits for Foreign Workers and regulation of the Ministry of Law and Human Rights Number 26 of 2020 concerning Visas and Stay Permits in the New Habit Adaptation Period. That regulation has required the foreigner to have a legal relationship with their employer, which means there is no specific regulation related to the digital nomad phenomenon.

The absence of regulations that bind digital nomads is a mandatory concern of the Indonesian Government, especially the Directorate General of Immigration, who can reflect on countries in the world that have issued visas to accommodate digital nomads. One country that has gone one step further is Estonia, which in June 2020 opened a digital nomad and freelancer visa application that is valid for one year using the digital special visa.

\section{CONCLUSION}


The Digital Nomad is a new social phenomenon that happens in almost all of the world. Digital working platforms, such as freelancer.com, fiverr.com, and gigs.com are enabling millennials workers to do their job without any geographical nor time boundaries. In other words, the millennial workers mostly came from Advanced Economies, can have vacation and work at the same time. Tourist-friendly places like Indonesia (Bali, Lombok, and Yogyakarta) and Thailand (Pattaya) are becoming primary destinations, as released by the digital nomad communities (nomadlist.com).

Kristen Gray and Her girlfriend stayed and worked in Bali as Digital Nomad from 21 January 2020 to 16 January 2021 with a tourist visa. Then, she tweets about her experiences, and conducts consultation services about moving to Bali as Digital Nomads, and "plays" with the tourist visa with an hourly pay of around US\$45. Surprisingly, after the data analysis is conducted, many of the digital nomad people are defending Kristen Gray, on the other hand, Indonesian are pushing the government to deport Kristen Gray and her girlfriend as soon as possible. They were changed for visa misuse as stated in the articles 75 Law number 06/2011 about Immigration.

Most of the digital nomads who lived especially in Bali, aged from 20 to 35 years old, have bachelor's or even a Ph.D. degree and can earn from US\$ 1000 to US\$ 5000 monthly. Then, the most important motivation for the digital nomads is the lower cost of living, cultural openness, and surprisingly they don't need to pay income taxes. Compared with the local workers who only can earn an average of US\$ 170 monthly, with an average high school degree, and low computational literacy. The differences in terms of income, culture, and standard of living potentially creating a gentrification phenomenon in the future. The absence of law which rules digital nomad is one of the main concerns, so the government should take any necessary action to make Indonesia as host countries for the digital nomad in South East Asia, suggesting special visas with the restriction and tax policy for the digital nomad. 


\section{REFERENCES}

M.G. (2017). Geodesic Based Centrality: Unifying the Local and The Global. Journal of Social Networks. Volume 49 (2017). Pp. 12-26. Doi: http://dx.doi.org/10.1016/j.socnet.2016.09. $\underline{005}$

Atkinson, R. (2000). Measuring Gentrification and Displacement in Greater London. Journal of Urban Studies, Volume 37(1), 149-165. https://doi.org/10.1080/0042098002339

Badan Pusat Statistik (BPS). (2020). Perkembangan Pariwisata dan Transportasi Nasional Desember 2020. Badan Pusat Statistik (BPS): Jakarta

BPS Provinsi Bali. (2020). Provinsi Bali dalam 2020. https://bali.bps.go.id/publication/2020/04/ 27/c2d74be21e44651b07e2658e/provinsibali-dalam-angka-2020.html.

Coconut, B. (29 January 2021). 'I Am Sorry': Kristen Gray Writes Public Apology Following Controversy. https://coconuts.co/bali/news/i-am-sorrykristen-gray-writes-public-apologyfollowing-controversy/.

Cook, D. (2020). The freedom trap: digital nomads and the use of disciplining practices to manage work/leisure boundaries. Journal of Information Technology \& Tourism (2020) 22:355390. https://doi.org/10.1007/s40558-020$\underline{00172-4}$

Direktorat Jenderal Anggaran. (2016). Efektivitas Alokasi Anggaran Kementerian Pariwisata terhadap Kunjungan Wisatawan Mancanegara dan Wisatawan Nusantara. Kementerian Keuangan Republik Indonesia: Jakarta.

Direktorat Jenderal Imigrasi, (2020). Laporan Akuntabilitas Kinerja Tahun 2020. Kementerian Hukum dan Hak Asasi Manusia Republik Indonesia: Jakarta.
E, McElroy. (2019). Digital nomads in siliconizing Cluj: Material and allegorical double dispossession. Journal of Urban Studies. Year 2020; Volume 57(15):30783094. doi:10.1177/0042098019847448

European Union. (2016). The EU in 2016. European Union. https://op.europa.eu/webpub/com/generalreport-2016/en/

Formica, P. 2013. Stories of Innovation for The Millennial Generation: The Lynceus Long View. Springer Publishing: United States of America.

Gani, P.K. (2019). ASEAN Travel Infographics: Facts \& Recommendation. Lembaga Penelitian dan Pengabdian kepada Masyarakat London School of Public Relations: Jakarta

Gil-Or, O. (2011). Social Networks and Social Isolation - A Reason and Its Solution in One. Journal of PRAGYAA- Journal of Management. 2. 1-7. Doi:

https://www.researchgate.net/publication/2 61704749_Social_networks_and_social_is olation -

A_reason_and_its_solution_in_one

Guerreri, V., Hartley, D. \& Hurst, E. (2013). Endogenous gentrification and housing price dynamics. Journal of Public Economics Volume 100, April 2013, Pp. 45-60.

Doi:

https://doi.org/10.1016/j.jpubeco.2013.02. $\underline{001}$

Haking, J. (2017). Digital Nomad Lifestyle. (Publication No. 1163) [Master Dissertation, KTH Royal Institute of Technology]. KTH Campus Repository. http://kth.diva-

portal.org/smash/record.jsf?pid=diva2:118 $\underline{2328}$

Helms, A. C. (2003). Understanding gentrification: an empirical analysis of the determinants of urban housing renovation. Journal of Urban Economics, Elsevier, vol. 
54(3), pages 474-498, November. Doi: https://ideas.repec.org/a/eee/juecon/v54y2 003i3p474-498.html

Indonesian Presidential Studies (IPS). (2021). Kaum Muda \& Perkembangan Dunia Pekerjaan Di Era Digital. Youth Studies Center, FISIPOL UGM Reports, March - April 2021.

Kanwil Bali. (2021). Langkah Cepat Imigrasi Bali Menanggapi Pemberitaan Viral Terkait Cuitan Akun Twitter Warga Negara Asing @Kristentootie. Retrieved from

https://bali.kemenkumham.go.id/beritakanwil/berita-utama/3447-langkah-cepatimigrasi-bali-menanggapi-pemberitaanviral-terkait-cuitan-akun-twitter-warganegara-asing-kristentootie (19 January 2021).

Kolko, J. (2007), The Determinants of Gentrification. Master Dissertation. http://dx.doi.org/10.2139/ssrn.985714

Kusumadjaja, L. (2014), The impact of viral marketing through social media on $B C D$ 's consumer brand knowledge. Journal of iBuss Management, 2(2), Pp. 162-172.

Lingel. J. (13 March 2019). The Gentrification of The Internet. https://culturedigitally.org/2019/03/thegentrification-of-the-internet/

Manik, Y.M., Sutanta, H., \& Diyono. (2017). Analisis Pemangku Kepentingan Dan Peranannya Dalam Pemanfaatan Informasi Geospasial Di Pemerintah Daerah Menggunakan Metode Social Network Analysis. [Conference Paper]. Seminar Nasional Geomatika 2017: Inovasi Teknologi Penyediaan Informasi Geospasial untuk Pembangunan Berkelanjutan. Pp. 409-418. http://semnas.big.go.id/index.php/SN/articl e/viewFile/436/83

Mohn, T. (2014). How to Succeed at Becoming A Digital Nomad. Forbes.com. https://www.forbes.com/sites/tanyamohn/2 014/03/19/tips-for-becoming-a-successfuldigital-nomad/?sh=711b6c90416b.

Nash, C., Jarrahi, M.H. Sutherland, W. \& Phillips, G. (2017). Digital nomads beyond the buzzword: Defining digital nomadic work and use of digital technologies. (Essay).

https://www.researchgate.net/profile/Moha mmad-Hossein

Jarrahi/publication/322923942_Digital_no mads beyond the buzzword_Defining di gital_nomadic_work_and_use_of_digital_t echnologies/links/5a7655a5a6fdccbb3c07a f06/Digital-nomads-beyond-the-buzzwordDefining-digital-nomadic-work-and-useof-digital-technologies.pdf

Nomadlist. (2021). Best places to live as Digital

Nomad.

https://nomadlist.com/canggu

Olga, H. (2020). In search of a digital nomad: defining the phenomenon. Journal of Information Technology \&

Tourism (2020) 22:335-353. https://doi.org/10.1007/s40558-020$\underline{00177-\mathrm{Z}}$

Pratiyudha, P.P. (2019). Gentrifikasi Dan Akar-Akar Masalah Sosial: Menakar Identifikasi, Diagnosis, Dan Treatment Proses Gentrifikasi Sebagai Masalah Sosial. Journal of Reka Ruang, Vol.2, No.1, 2019, pp.27-38. Doi: https://journal.itny.ac.id/index.php/rekarua ng/index.php

Prabawa, I, W, S, W, \& Pertiwi, P.R. (2020). The Digital Nomad Tourist Motivation in Bali: Exploratory Research Based on Push and Pull Theory. Journal of Athens Tourism - Volume 7, Issue 3, September 2020, Pp.161-174. Doi: https://www.athensjournals.gr/tourism/202 0-7-3-3-Prabawa.pdf

Prester, J., Kecmanovic, D.C., \& Schalagwein, D. (2020). Becoming a Digital Nomad: Identity Emergence in the 
Flow of Practice. (Short Essay). https://www.researchgate.net/profile/Julian

Prester/publication/336210364_Becoming _a_Digital_Nomad_Identity_Emergence_i n the Flow_of_Practice/links/5d9477682 99bf10cff1ff27f/Becoming-a-DigitalNomad-Identity-Emergence-in-the-Flowof-Practice.pdf

Reichenberg. I. (2018). Digital nomads $-a$ quest for holistic freedom in work and leisure. Journal of Annals of Leisure Research, 21:3, 364-

380, DOI: $\underline{10.1080 / 11745398.2017 .13580}$ $\underline{98}$

Retyan, S \& Muslimah, S. (20 January 2021). Ini Daftar Pelanggaran Kristen Gray Selama di Bali Hingga Akhirnya Dideportasi. Kumparan News. https://kumparan.com/kumparannews/inidaftar-pelanggaran-kristen-gray-selama-dibali-hingga-akhirnya-dideportasi1v0vinSOC99/full.

Scandasia. (15 January 2021). Top Asian places for remote working in 2021. https://scandasia.com/top-asian-places-forremote-working-in-2021/

Sofronov, B. (2018). The Development of the Travel and Tourism Industry in the World. Journal of Annals of Spiru Haret University. Economic Series, 18(4), 123137, doi: https://doi.org/10.26458/1848

Smith, L \& Zhu, L \& Lerman, K \& Kozareva, Z. (2013). The Role of Social Media in the Discussion of Controversial Topics. Proceedings

SocialCom/PASSAT/BigData/EconCom/B ioMedCom 2013. Pp. 236-243. Doi: 10.1109/SocialCom.2013.41.

Thompson, B.Y. (2019). The Digital Nomad Lifestyle: (Remote) Work/Leisure Balance, Privilege, and Constructed Community. Journal of International Social Leis 2, 27-42 (2019). https://doi.org/10.1007/s41978-01800030-
Tomasoa, L., Iriani, D, \& Sembiring, I. (2019). Ekstraksi Knowledge Tentang Penyebaran \#Ratnamiliksiapa Pada Jejaring Sosial (Twitter) Menggunakan Social Network Analysis (SNA). Jurnal Teknologi Informasi dan Ilmu Komputer (JTIIK). Vol.6, No.6, Desember 2019, Pp. 677-686. Doi: 10.25126/jtiik.201961710

Takama, T. (23 January 2021). [Bali life] Reality of Digital Nomads in Bali. https://www.su-re.co/post/bali-life-realityof-nomad-workers-in-bali

Wiloyudho, S. (2014). Migrasi Dan Involusi Di Kota Semarang (Migration and Involution in Semarang City). Journal of Manusia Dan Lingkungan, Vol. 21, No.1, Maret. 2014: 114-120. Doi: https://jurnal.ugm.ac.id/JML/article/downl oad/18519/11812

Yavich, R, Davidovitch, N \& Frenkel, Z. (2019). Social Media and Loneliness Forever Connected? Journal of Higher Education Studies. Volume 9. Doi: 10. 10.5539/hes.v9n2p10 